\title{
The dynamics of innovation in the ex- communist countries in Europe in the context of globalization
}

\author{
Florina Bran $^{1}$, Marcela Antoaneta Niculescu $^{1}$, Victor Marian Dumitrache ${ }^{1,{ }^{*}}$, and Svetlana \\ Platagea Gombos ${ }^{1}$ \\ ${ }^{1}$ The Bucharest University of Economic Studies, PhD student, Piata Romana nr. 6, 010374, \\ Bucharest, Romania
}

\begin{abstract}
.
Research background: Even if they share a similar background, the excommunist European countries have started since the '90s to differentiate one from another in terms of development. Nowadays, the gaps between them are significant in many aspects of the socio-economic environment, including innovation. Measurements done by Cornell University, INSEAD, and WIPO through the Global Innovation Index give us the opportunity to compare the achievements from the last 30 years of the ex-communist countries.

Purpose of the article: The purpose of this paper is to point out the major gaps between the European ex-communist countries in terms of innovation - both innovation inputs and innovation outputs - in the context of globalization, and the way the globalization fostered or suppressed the innovation.

Methods: We will do a comparative analysis of the indicators that the input and output indexes are based on - regulatory environment, education, general infrastructure, credit, investment, knowledge workers, knowledge creation, knowledge impact, online creativity, intangible assets.

Findings \& Value added: This paper may add value to the economic and educational policies in the ex-communist countries by identifying the policies that proved their effectiveness in increasing innovation rates, policies that can be adapted and then adopted by the ex-communist countries that are less innovative.
\end{abstract}

Keywords: innovation; globalization; ex-communist countries in Europe

JEL Classification: $O 30 ; F 63$

* Corresponding author: victor.dumitrache@gmail.com 


\section{Research background}

Economic development is based on 3 major elements, according to the exogenous growth model: a) capital accumulation - including real estate investments, equipment, and human resources; b) population growth, including labour; c) technological progress reflected in higher productivity rates [1]. Globalization has had a nurturing effect on each of these elements and it has changed their dynamics. Capital accumulation is not limited by location or geography, population fluctuations are significantly affected by migration and technological progress has never been so easy to align with especially for the least developed countries.

In the past century, there was another major growth theory that has emerged, explaining the role and the importance of technological progress in economic growth, stating that innovation is the main driver for economic development.

According to the endogenous growth theory, the second main theory, developed by Romer [2] and Aghion and Howitt [3], technological innovation and knowledge diffusion are the key approaches under which workers' educational achievement influences economic growth. As innovation is a function of human capital invested in $\mathrm{R} \& \mathrm{D}$, when examining the innovation output, we have to treat human capital and finance as separate variables. [4]

Due to the global economy characteristics such us the intensification of globalization and the transition to industry 4.0, the use of modern technology in production is no longer a competitive advantage by itself [5]. However, Zheng et al. [6] show that overall globalization only has a significantly positive influence on innovation output in the least innovative countries and that globalization leads to better innovation performance in the medium innovative countries among OECD countries.

We can observe this influence reflected in the productivity trends measured by DGP/capita in the 8 ex-communist countries (table 1): in 1997, the least productive country was Romania, while the most productive was Slovenia with a GDP/capita 2.75 times higher than Romania's. 22 years after, in 2019, we can see that Slovenia has a GDP/capita only 2.4 times higher than 1997, while Romania has increased it 4.75 times more. Now, the GDP/capita in Slovenia is only 1.38 times higher than in Romania.

Bridging the gap of innovation through trade activities, information exchange, and policy diffusion and thus increasing its productivity reflected by GDP/capita, bridged the gap between the least and the most developed country from our ex-communist countries cluster. On one hand, higher trade integration accelerates the exchange of technology ideas, creates more opportunities for domestic firms to observe and learn through horizontal comparisons in the same industry or technology transfer in the supply chain, stimulates the mobility of skilled labour, and promotes trade in technology, which in turn enhance the facilitation of technology diffusion [7-13].

\section{Purpose of the article}

The purpose of this paper is to point out the major gaps between $8 \mathrm{EU}$ ex-communist countries - Czech Republic, Slovenia, Hungary, Slovakia, Poland, Bulgaria, Croatia, and Romania - in terms of innovation (both innovation inputs and innovation outputs) in the context of globalization. We considered that is more relevant to compare 8 countries that have similar background before the '90s, that entered democracy and capitalism almost in the same period of time and that are all part of the EU at this moment. Based on Global Innovation Index (GII), in 2019, our of 129 countries worldwide, the highest rated among the 8 was Czech Republic $\left(26^{\text {th }}\right)$ with a GII score of 49.4 and the lowest rated was Romania $\left(25^{\text {th }}\right)$ with a GII score of 36.8 as shown in table 2 . 
Table 1. The 8 EU ex-communist countries sorted by GDP/capita in 2019.

\begin{tabular}{|c|c|c|}
\hline Country & GDP/Capita 2019, PPP\$ & GDP/Capita 1997, PPP\$ \\
\hline Czech Republic & 37370.97 & 14727.91 \\
\hline Slovenia & 36745.89 & 15277.65 \\
\hline Slovakia & 35129.79 & 10082.63 \\
\hline Poland & 31938.66 & 8920.16 \\
\hline Hungary & 31902.67 & 9821.53 \\
\hline Romania & 26446.74 & 5562.19 \\
\hline Croatia & 26221.43 & 9461.58 \\
\hline Bulgaria & 23155.64 & 5748.48 \\
\hline
\end{tabular}

Table 2. Ex-communist EU countries sorted by GII rank.

\begin{tabular}{|c|c|c|}
\hline Country & GII Rank & GII Score \\
\hline Czech Republic & 26 & 49.4 \\
\hline Slovenia & 31 & 45.3 \\
\hline Hungary & 33 & 44.5 \\
\hline Slovakia & 37 & 42 \\
\hline Poland & 39 & 41.3 \\
\hline Bulgaria & 40 & 40.3 \\
\hline Croatia & 44 & 37.8 \\
\hline Romania & 50 & 36.8 \\
\hline
\end{tabular}

\section{Methods}

The current comparative analysis among the $8 \mathrm{EU}$ ex-communist countries relies on Global Innovation Index (GII) raw data that can be found in the Global Innovation Index 2019, $12^{\text {th }}$ edition [14]. The relevant data were aggregated by the authors in a spreadsheet where it was processed and where histograms were generated.

The GII is based on two sub-indices: Innovation Input Sub-Index built on 5 key pillars and the Innovation Output Sub-Index built on 2 key pillars.

Five input pillars capture elements of the national economy that enable innovative activities: (1) Institutions, (2) Human capital and research, (3) Infrastructure, (4) Market sophistication, and (5) Business sophistication. Two output pillars capture actual evidence of innovation outputs: (6) Knowledge and technology outputs and (7) Creative outputs [15].

Each pillar is divided into 3 sub-pillars and each sub-pillar is composed of individual indicators (80 in total in 2019). Sub-pillar scores are calculated as the weighted average of 
individual indicators; pillar scores are calculated as the weighted average of sub-pillar scores.

For serving the purpose of this article, the analysis is done at sub-pillar level, comparing the $8 \mathrm{EU}$ ex-communist countries between them by the score they register in each subpillar. For in depth analysis, in some of the sub-pillars, we analysed the indicators composing the sub-pillar as well, especially to explain what the route cause of the differences between the highest and the lowest rated countries.

\section{Results}

The following 5 pillars analysed below describe the innovation input.

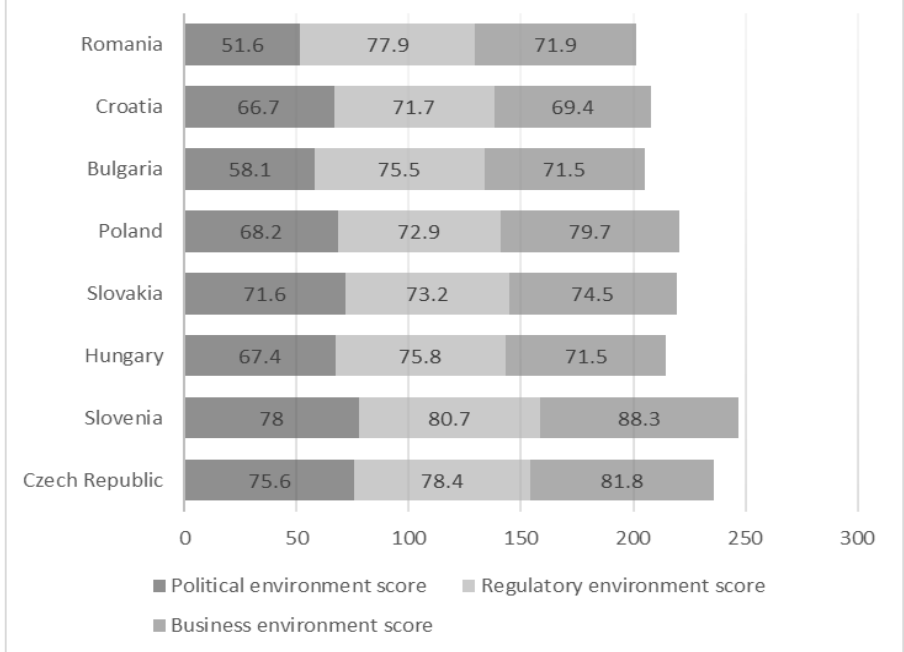

Fig. 1. Pillar 1 - Institutions, with its 3 sub-pillars.

The Institutions pillar shows overall homogeneity among the 8 countries, with Slovenia slightly differentiated among all.

The scores in Political environment sub-pillar range from 51.6 (Romania) to 78 (Slovenia) with Romania underscoring in Government effectiveness (ranked 84 worldwide out of 129 countries).

The scores in Regulatory environment sub-pillar range from 71.7 (Croatia) to 80.7 (Slovenia) with no noticeable differences among countries.

The scores in Business environment sub-pillar range from 69.4 (Croatia) to 88.3 (Slovenia) with Croatia underscoring in the ease of starting a business (ranked 95 worldwide out of 129 countries).

We suggest that overall, in the WII index, Institutions pillar is a minor differentiator among the 8 countries. 


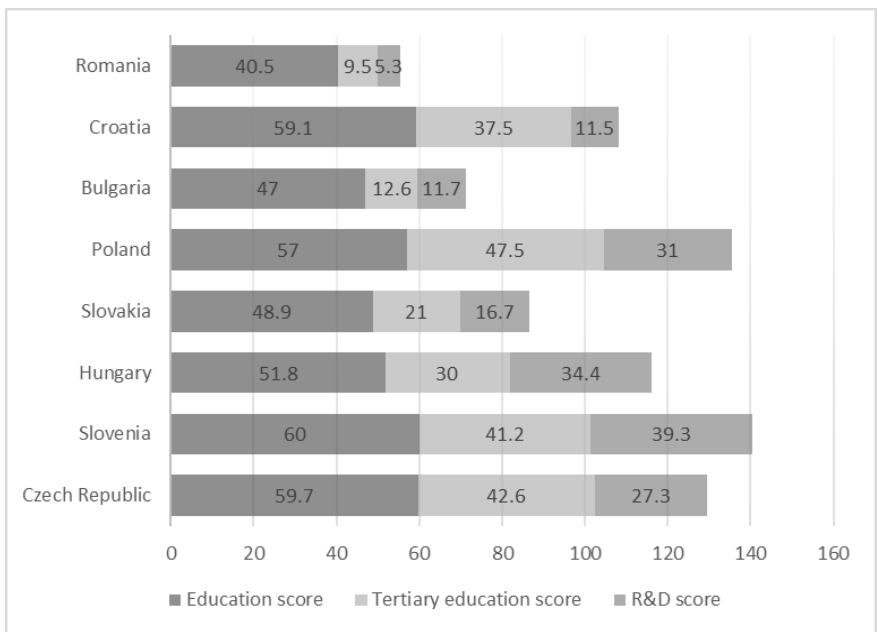

Fig. 2. Pillar 2 - Human capital and research, with its 3 sub-pillars.

The Human capital and research pillar shows overall significant differences among the 8 countries with even larger gaps at sub-pillar level.

Czech Republic, Slovenia, Poland, and Croatia are clustered together with scores ranging from 57 (Poland) and 60 (Slovenia) in Education sub-pillar. Another cluster is represented by Bulgaria (47), Hungary (51.8), and Slovakia 48.9). Romania cannot be clustered with any other country having a score of 40.5 . The poor performance of Romania in Education (ranked 82 out of 129 countries) is mainly because of its low expenditure (as $\%$ GDP) on primary and secondary education.

The gap is even larger in Tertiary education pillar, with Czech Republic, Slovenia, Poland, and Croatia having a scoring range 37.5 (Croatia) and 47.5 (Poland) thus forming together a cluster. They are followed by Hungary (30) and Slovakia (21). The poorest performers in Tertiary education are Bulgaria scoring 12.6 and Romania scoring 9.5, both having lower enrolment rated in tertiary education and lower number of foreign students being hosted international study programs comparing to the other 6 countries. However, regarding tertiary education, Romania is ranked higher worldwide (17 out of 129 countries) by the number of graduates in science and engineering.

In Research and development sector, the third sub-pillar, Czech Republic, Slovenia, Poland, and Hungary are clustered together with scores between 27.3 (Czech Republic) and 39.3 (Slovenia). Another cluster is formed by Croatia, Slovakia and Bulgaria with scores ranging from 11.5 (Bulgaria) to 16.7 (Slovakia). Romania cannot be clustered with any other country as it scores 5.3. There are two reasons why Romania has this poor performance: 1) in two of the four indicators composing Research and development subpillar, Romania scores 0: Average expenditure on $R \& D$ of the top three global companies and QS university ranking average score of top 3 universities. 2) in the other two indicators, Researchers per million population, full-time equivalence, and Gross expenditure on $R \& D$ underperforms being ranked 52, respectively 64 out of 129 worldwide.

We suggest that overall, in the WII index, Human capital and research pillar is strong differentiator among the 8 countries. 


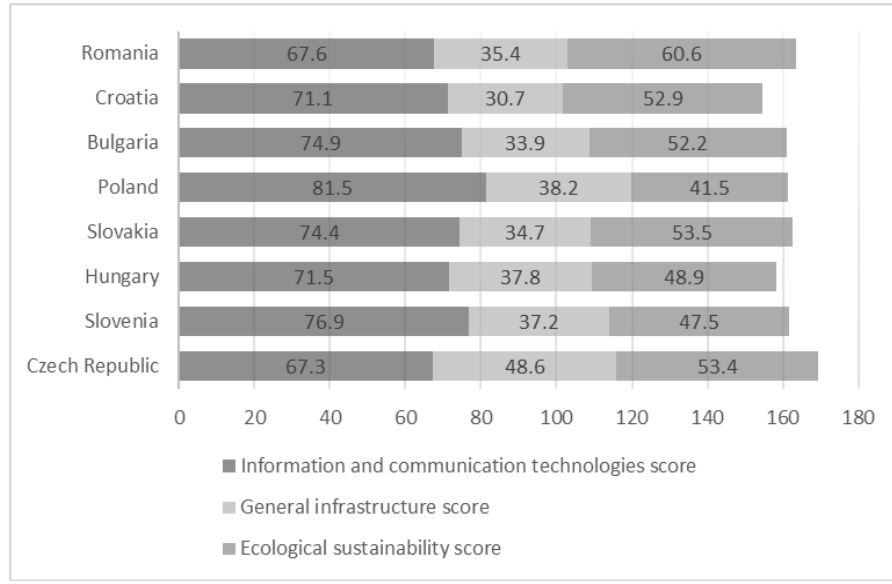

Fig. 3. Pillar 3 - Infrastructure, with its 3 sub-pillars.

The Infrastructure pillar shows overall homogeneity among the 8 countries, with rather insignificant differences at sub-pillar level.

The scores in Information and communication technologies sub-pillar range from 81.5 (Poland) to 67.3 (Czech Republic) with Poland ranking slightly higher in Government's online service - ranked as $17^{\text {th }}$ worldwide.

The scores in General infrastructure sub-pillar range from 48.6 (Czech Republic) to 30.7 (Croatia) with Czech Republic ranking slightly higher due to its higher electricity production and its logistics performance.

The scores in Ecological sustainability sub-pillar range from 41.5 (Poland) to 60.6 (Romania) with Poland scoring lower in GDP per unit of energy use (ranked $57^{\text {th }}$ worldwide out of 129 countries) and with Romania scoring higher in ISO 14001 environmental certificates (ranked $4^{\text {th }}$ worldwide out of 129 countries).

We suggest that, overall, in the WII index, Infrastructure pillar is minor differentiator among the 8 countries.

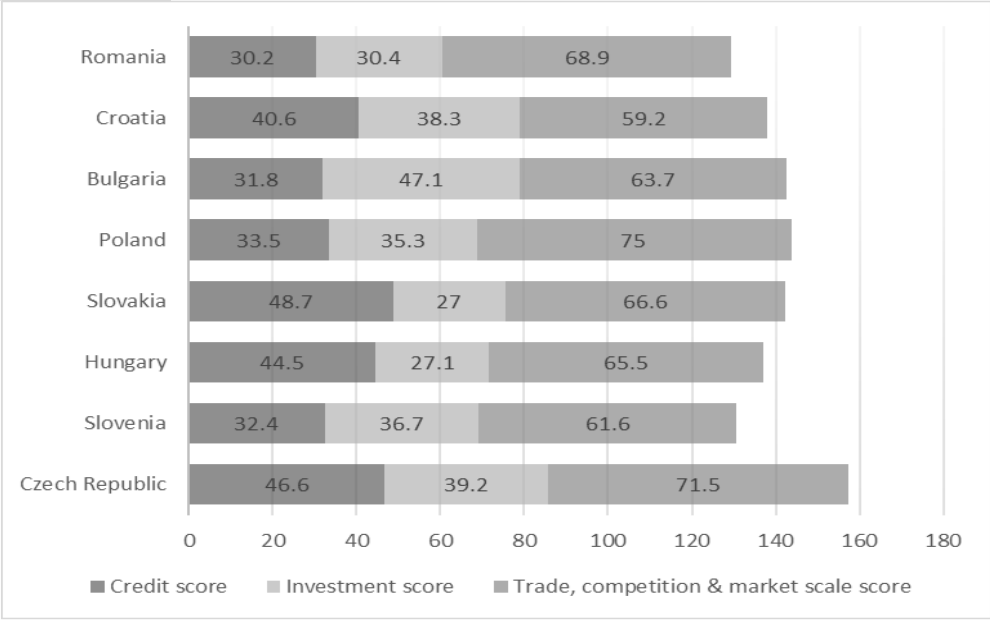

Fig. 4. Pillar 4 - Market sophistication, with its 3 sub-pillars.

The Market sophistication pillar shows overall homogeneity among the 8 countries, with some differences at sub-pillar level. 
The scores in Credit sub-pillar range from 30.2 (Romania) to 48.7 (Slovakia), with Romania underperforming in Domestic credit to private sector indicator $\left(103^{\text {rd }}\right.$ worldwide out of 129 countries). This indicator refers to financial resources provided to the private sector by financial corporations, such as through loans, purchases of nonequity securities, and trade credits and other accounts receivable, that establish a claim for repayment.

The scores in Investment sub-pillar range from 27 (Slovakia) to 47 (Bulgaria), with Slovakia underperforming in Investment (ranked $125^{\text {th }}$ worldwide out of 129 countries) because of its poor market capitalization, the lack of venture capital deals and the lack of measures protecting minority investors.

The scores in Trade, competition \& market scale sub-pillar range from 59.2 (Croatia) to 75 (Poland), with Poland scoring very well in Domestic market scale and with Croatia underscoring in Intensity of local competition.

We suggest that, overall, in the WII index, Market sophistication pillar is a relevant differentiator among the 8 countries.

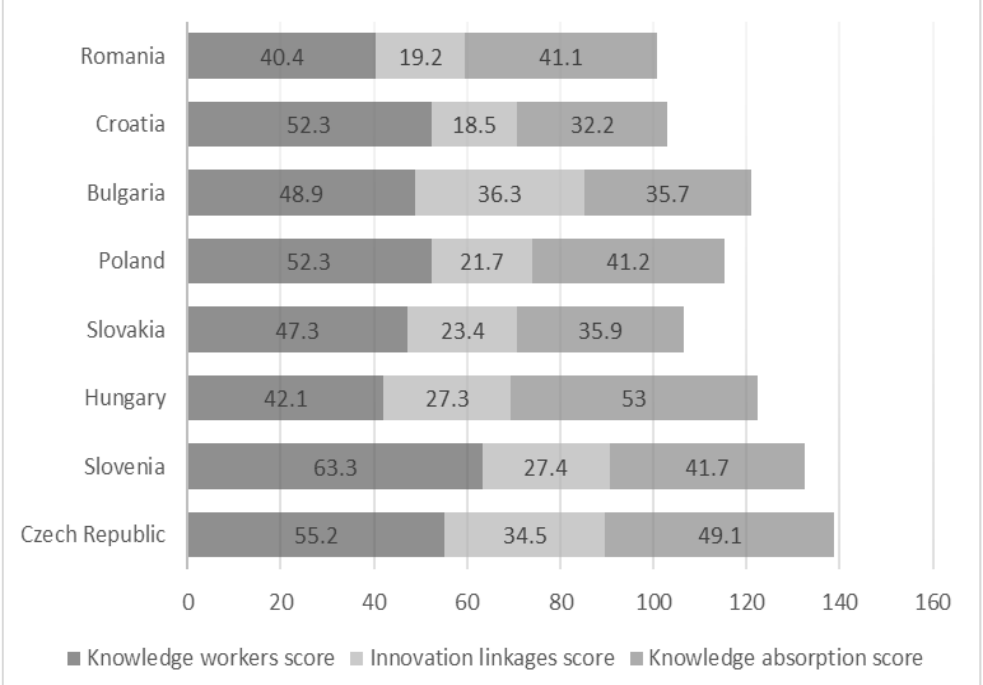

Fig. 5. Pillar 5 - Business sophistication, with its 3 sub-pillars.

The Business sophistication pillar shows overall significant differences among the 8 countries, even if at sub-pillar level the gaps are moderate indicating homogeneity rather than heterogeneity.

The scores in Knowledge workers sub-pillar range from 40.4 (Romania) to 63.3 (Slovenia) with Slovenia having a high gross expenditure on R\&D financed by business enterprise as a percentage of total gross expenditure on R\&D (ranked $6^{\text {th }}$ worldwide out of 129 countries).

The scores in Innovation linkages sub-pillar range from 18.5 (Croatia) to 36.3 (Bulgaria), with Croatia underperforming in university/industry research collaboration (ranked $111^{\text {th }}$ worldwide out of 129 countries) and in state of development cluster (ranked $119^{\text {th }}$ worldwide out of 129 countries).

The scores in Knowledge absorption sub-pillar range from 32.2 (Croatia) to 53 (Hungary), with Croatia underperforming in High-tech imports (ranked $91^{\text {st }}$ worldwide out of 129 countries) and with Hungary performing very well in Net foreign direct investment inflow (ranked $9^{\text {th }}$ worldwide), in Research talent in business enterprise (ranked $11^{\text {th }}$ worldwide) and High-tech imports (ranked $17^{\text {th }}$ worldwide).

We suggest that, overall, in the WII index, Business sophistication pillar is a rather significant differentiator among the 8 countries. 
The following two pillars describe the innovation output.

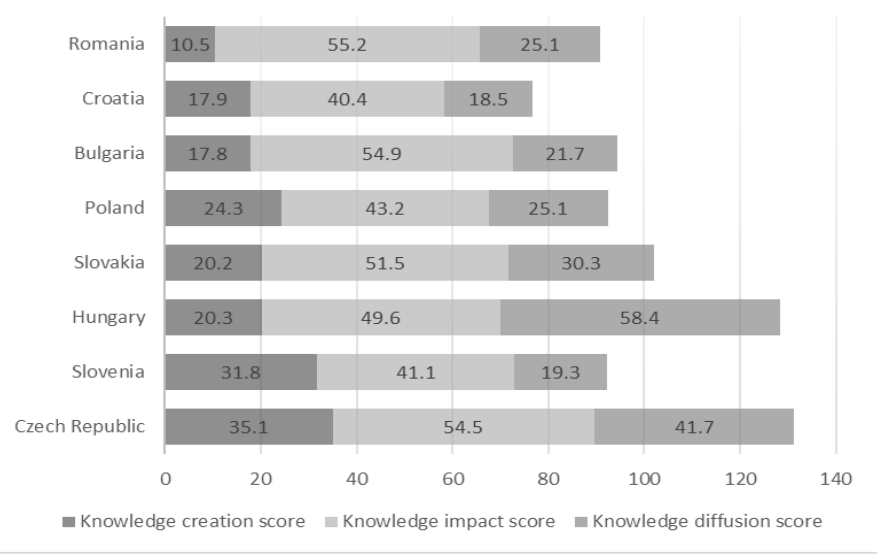

Fig. 6. Pillar 6 - Knowledge and technology outputs, with its 3 sub-pillars

The Knowledge and technology output pillar shows overall significant differences among the 8 countries.

The scores in Knowledge creation sub-pillar range from 10.5 (Romania) to 35.1 (Czech Republic), with Romania having a low number of international patent applications filed by residents at the Patent Cooperation Treaty (ranked 73 worldwide).

The score in Knowledge impact sub-pillar range from 40.4 (Croatia) to 55.2 (Romania), with Romania having a high growth rate of GDP pe person engaged (ranked $11^{\text {th }}$ worldwide) and with Croatia underperforming in Total computer software spending (ranked $99^{\text {th }}$ worldwide).

The score in Knowledge diffusion sub-pillar range from 18.5 (Croatia) to 58.4 (Hungary), with Croatia having a low foreign direct investment, net outflow compared to the country's GDP(ranked $88^{\text {th }}$ worldwide) while Hungary registered the highest foreign direct investment, net outflow compared to the country's GDP (ranked $1^{\text {st }}$ worldwide).

We suggest that, overall, in the WII index, Knowledge and technology outputs pillar is a rather significant differentiator among the 8 countries.

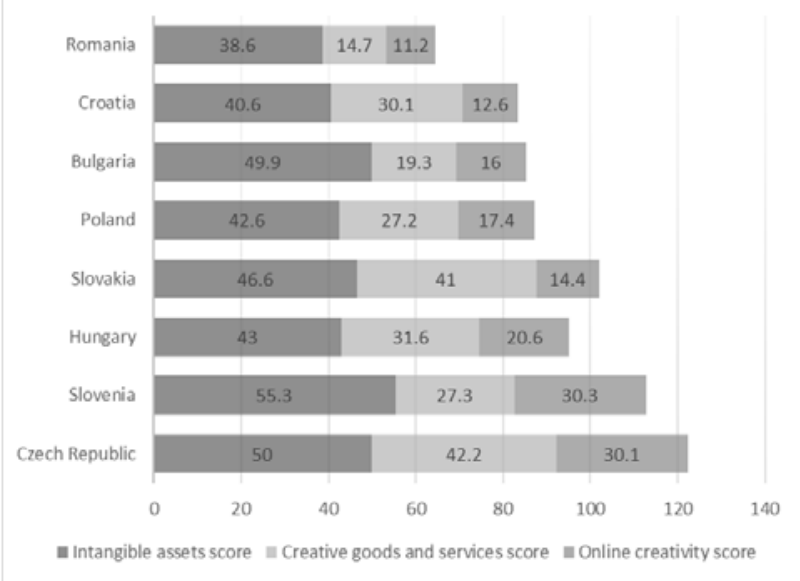

Fig. 7. Pillar 7 - Online creativity, with its 3 sub-pillars

The Creative outputs pillar shows overall significant gaps among the 8 countries. 
The scores in Intangible assets sub-pillar range from 38.6 (Romania) to 55.3 (Slovenia) with Romanian ICTs having lower influence on the creation of new organizational models (ranked 81 worldwide).

The scores in Creative goods and services sub-pillar range from 14.7 (Romania) to 42.2 (Czech Republic), with Czech Republic ranked $1^{\text {st }}$ worldwide in total value of creative goods exports over total trade.

The scores in Online creativity range from 11.2 (Romania) to 30.3 (Slovenia), with Slovenia performing well in Wikipedia yearly page edits (ranked $12^{\text {th }}$ worldwide).

We suggest that, overall, in the WII index, Online creativity pillar is a rather significant differentiator among the 8 countries.

\section{Conclusions}

The comparative analysis among the 8 EU ex-communist countries reveals the following:

Institutions pillar is a minor differentiator among the 8 countries. Political environment, Regulatory environment and Business environment are rather similar, with Slovenia performing slightly better in the ease of starting a business.

Human capital and research pillar is strong differentiator among the 8 countries, with Romania having the poorest performance in Education sub-pillar caused mainly by its low expenditure (as \%GDP) on primary and secondary edu320cation, unfortunately with negative impact on innovation and economic growth in the long-run. Also, Bulgaria and Romania underperform in Tertiary education sub-pillar as well, both having low enrolment rate in tertiary education and a low number of foreign students. This can be interpreted as a downside of globalization affecting the least developed countries whose tertiary education systems compete with the systems of the neighbour countries, where those with higher quality education attract more students and, on the long term, generate a more sustainable growth based on human capital accumulation and higher capacity to innovate. In a highly competitive European education environment, developing academic excellence in a particular field of study and promotive it worldwide may be a good strategy for the least developed countries to retain local high school graduates and to attract foreign students as well. The model of Carol Davila University of Medicine and Pharmacy from Bucharest is worth to be further documented from this perspective.

Romania underscores in R\&D sub-pillar as well among the 8 countries, having the lowest number of researchers per million population and having no private investment in R\&D from the top 3 global companies.

Infrastructure pillar shows overall homogeneity among the 8 countries, with rather insignificant differences at sub-pillar level like Poland performing above average in Government's online service and Czech Republic in electricity production. Thus, we consider it a minor differentiator among the 8 countries.

Market sophistication pillar is a relevant differentiator among the 8 countries showing overall homogeneity, with some differences at sub-pillar level. The gaps are created by Domestic credit to private sector indicator where Romania underperforms and by poor market capitalization, the lack of venture capital deals and the lack of measures protecting minority investors in Slovakia.

Business sophistication pillar is a rather significant differentiator among the 8 countries, with Slovenia registering the highest rate of R\&D financed by business enterprise to total gross expenditure on $\mathrm{R} \& \mathrm{D}$, that can be linked to the high attractiveness of the tertiary education system; with Croatia underperforming in university/industry research collaboration; and with Hungary performing very well in Net foreign direct investment inflow. 
Knowledge and technology outputs pillar is a rather significant differentiator among the 8 countries with Romania with Romania having a high growth rate of GDP pe person engaged (and with Croatia underperforming in Total computer software spending while Hungary registered the highest foreign direct investment, net outflow.

Online creativity pillar is a rather significant differentiator among the 8 countries, with Czech Republic ranked 1st worldwide in total value of creative goods exports over total trade and with Romanian ICTs having lower influence on the creation of new organizational models.

\section{References}

1. Todaro, M. P. (1997). Economic Development. 6th Edition, New York: Pearson.

2. Romer, P. M. (1990). Endogenous technological change. Journal of political Economy, 98(5,2), 71-102.

3. Aghion, P., Howitt, P. (1992). A model of growth through creative destruction. Econometrica, 60(2), 323-351.

4. Arjun, K., Sankaran, A., Sanjay, K., Mousumi, D. (2020). An endogenous growth approach on the role of energy, human capital, finance and technology in explaining manufacturing value-added: A multi-country analysis. Heliyon, 6(7), e04308.

5. Garavan, T. et al. (2001). Human Capital Accumulation: The Role of Human Resource Development, Journal of European Industrial Training, 25(2-4), 48-68.

6. Zheng, M., Feng, G.F., Feng, S., Yuan, X. (2019). The road to innovation vs. the role of globalisation: A dynamic quantile investigation. Economic Modeling Journal, 83, 65-83.

7. Grossman, G. M., Helpman, E. (1995). Chapter 25 Technology and trade. Handbook of International Economics, 3, 1279-1337.

8. Spulber, D. F. (2007). Innovation and international trade in technology. Journal of Economic Theory, 138, 1-20.

9. Kiriyama, N. (2012), Trade and Innovation: Synthesis Report, OECD Trade Policy Papers, No. 135. Paris: OECD Publishing.

10. Chen, Z., Jie, Z., Wenping, Z. (2017). Import and innovation: Evidence from Chinese firms. European Economic Review, 94, 205-220.

11. Febiyansah, P. (2017). Indonesia's FDI - exports - GDP growth nexus: trade or investment - driven?. Buletin Ekonomi Moneter Dan Perbankan, 19(4), 469-488.

12. Pradhan, R. P., Arvin, M. B., Bahmani, S., Bennett, S. E. (2017). The innovationgrowth link in OECD countries: Could other macroeconomic variables matter?. Technology in Society, 51, 113-123.

13. Hausman, A., Johnston, J. W. (2014). The role of innovation in driving the economy: Lessons from the global financial crisis. Journal of Business Research, 67, 2720-2726.

14. Global Innovation Index (2019). Analysis Explore economy profiles from the GII. Retrieved from : https://www.globalinnovationindex.org/analysis-economy

15. Dutta, S., Lanvin, B., Wunsch-Vincent, S. (2019). The Global Innovation Index 2019 : Creating Healthy Lives-The Future of Medical Innovation. Retrieved from: https://www.wipo.int/edocs/pubdocs/en/wipo_pub_gii_2019.pdf 